\title{
ANALISIS PENGARUH PENYIMPANAN TERHADAP KADAR VITAMIN C PADA CABAI RAWIT (Capsicum frutuscens L) DAN CABAI MERAH BESAR (Capsicum annum L) DENGAN METODE SPEKTROFOTOMETRI
}

\author{
Rezqi Handayani', Nurul Qamariah², Tri Agung Rizky ${ }^{3}$ \\ 1,2,3 Program Studi DIII Farmasi Fakultas IImu Kesehatan Universitas Muhammadiyah \\ Palangkaraya \\ E-mail : rezqihandayani79@gmail.com
}

\begin{abstract}
ABSTRAK
Cabai merupakan salah satu buah-buahan yang mengandung vitamin $C$ dalam jumlah yang sangat besar. Vitamin C merupakan salah satu vitamin yang sangat diperlukan oleh tubuh tetapi tidak dapat disintesis di dalam tubuh dan mempunyai khasiat penangkal radikal bebas yang akan memperlambat proses oksidasi yang terjadi di dalam tubuh. Salah satu karakteristik dari vitamin $\mathrm{C}$ adalah senyawa yang sangat mudah teroksidasi karena pengaruh panas, logam dan cahaya sehingga dalam penyimpanannya perlu perlakuan khusus untuk tetap menjaga kadarnya. Salah satu kebiasaan masyarakat dalam menyimpan cabai adalah pada suhu dingin. Hal ini dapat dipercaya dapat menjaga kondisi cabai untuk selalu segar. Tetapi belum diketahui apakah kondisi tersebut dapat menjamin kadar vitamin C di dalamnnya. Berdasarkan teori, penyimpanan optimal untuk cabai adalah pada suhu rendah antara $2-15^{\circ} \mathrm{C}$ dengan kelembaban $90-95 \%$ agar cabai tetap segar selama \pm 20 hari. Penelitian ini untuk mengetahui pengaruh lama penyimpanan terhadap kadar vitamin $\mathrm{C}$ pada cabai rawit dan cabai merah. Metode penelitian yang digunakan adalah analisis kuantitatif dengan mengukur kadar vitamin C pada cabai menggunakan spektrofotometri. Indikator hari penyimpanan yang digunakan pada penelitian ini adalah hari pertama, kedua, keempat dan keenam serta suhu yang digunakan adalah $4^{\circ} \mathrm{C}$. Hasil penelitian menunjukkan bahwa kadar vitamin $C$ pada cabai rawit segar adalah 88,19 $\pm 1,39 \mathrm{mg} / \mathrm{g}$, pada penyimpanan dua hari adalah $82,04 \pm 1,34 \mathrm{mg} / \mathrm{g}$, pada penyimpanan empat hari adalah $78,43 \pm$ $1,02 \mathrm{mg} / \mathrm{g}$ dan pada penyimpanan enam hari adalah $78,17 \pm 2,05 \mathrm{mg} / \mathrm{g}$. Hasil penelitian kadar vitamin C pada cabai merah segar adalah adalah $81,54 \pm 0,51 \mathrm{mg} / \mathrm{g}$, pada penyimpanan dua hari adalah 74,39 \pm 0,89 $\mathrm{mg} / \mathrm{g}$, pada penyimpanan empat hari adalah $42,49 \pm 0,77 \mathrm{mg} / \mathrm{g}$ dan pada penyimpanan enam hari adalah $42,83 \pm 0,17 \mathrm{mg} / \mathrm{g}$. Berdasarkan penelitian yang telah dilakukan pada cabai rawit dan cabai merah besar dapat disimpulkan, bahwa dengan suhu $4^{\circ} \mathrm{C}$ pada penyimpanan selama 2 hari, 4 hari dan 6 hari dalam lemari pendingin kadar vitamin $C$ tidak terjaga dengan baik.
\end{abstract}

Kata Kunci: Cabai Rawit, Cabai Merah Besar, Kadar Vitamin C 


\begin{abstract}
Chili is one of the fruits that contain vitamin $C$ in very large number. Vitamin $C$ is one of the vitamin that is needed but cannot be synthesized in the body and has free radical antidote properties which will slow down the oxidation process that occurs in the body. One of the characteristics of vitamin $\mathrm{C}$ is a compound that is very easily oxidized due to the influence of heat, metal and light so that in storage it needs special treatment to keep the levels low. One of the habits of the people in storing chili is in cold temperatures. This way trusted to maintain the condition of chili to always be fresh. But it is not yet known whether these conditions can guarantee vitamin $\mathrm{C}$ levels in them. Theoretically, the optimal storage for chili is at low temperatures between 2-150 C with humidity of $90-95 \%$ so that the chili remains fresh for \pm 20 days. This research is to find out whether or not there is an influence between storage time on vitamin $C$ levels in cayenne pepper and red. The research method used was quantitative analysis by measuring vitamin $\mathrm{C}$ levels in chili using a spectrophotometric instrument. The storage day indicator used in this study is the first, second, fourth and sixth day and the temperature used is $4^{\circ} \mathrm{C}$. The results of the study for vitamin $\mathrm{C}$ levels in fresh cayenne pepper were $88.19 \pm 1.39 \mathrm{mg} / \mathrm{g}$, at two days storage was $82.04 \pm 1.34 \mathrm{mg} / \mathrm{g}$, at four days storage was $78.43 \pm 1.02 \mathrm{mg} / \mathrm{g}$ and at six days storage was $78.17 \pm 2.05 \mathrm{mg} / \mathrm{g}$. The results of the study for vitamin $C$ levels in fresh red chili were $81.54 \pm 0.51 \mathrm{mg} / \mathrm{g}$, at two days storage was $74.39 \pm 0.89 \mathrm{mg} / \mathrm{g}$, at four days storage was $42.49 \pm 0.77 \mathrm{mg} / \mathrm{g}$ and at six days storage was $42.83 \pm 0.17 \mathrm{mg} / \mathrm{g}$. Based on research that has been done on cayenne pepper and large red chili it can be concluded, that with $4^{\circ} \mathrm{C}$ temperature in storage for 2 days, 4 days and 6 days in the refrigerator the levels of vitamin $\mathrm{C}$ are not well maintained.
\end{abstract}

Key Words: Cayenne Pepper, Big Red Chili, Levels of Vitamin C

\title{
PENDAHULUAN
}

Vitamin merupakan senyawa organik yang sangat penting dalam mempengaruhi proses metabolisme. Vitamin dibutuhkan tubuh dalam jumlah kecil untuk mempertahankan kesehatan, tetapi vitamin tidak dapat disintesis di dalam tubuh manusia. Untuk memenuhi kebutuhan akan vitamin tersebut, manusia harus memperolehnya dari bahan pangan atau sediaan multivitamin. Tanpa adanya vitamin, manusia, hewan, dan makhluk hidup lainnya tidak akan dapat melakukan aktivitas dan dapat menyebabkan peluang terjadinya penyakit pada tubuh. Vitamin dapat dibagi menjadi dua macam yaitu vitamin yang larut dalam air $\left(B_{1}, B_{2}, B_{5}, B_{6}, B_{12}\right.$ dan $C)$ dan vitamin yang larut dalam lemak $(A$, D, E dan K) [1].

Salah satu vitamin yang diperlukan oleh tubuh adalah vitamin C. Vitamin C merupakan vitamin penting dan banyak digunakan dalam mengurangi gejala sariawan dan flu. Vitamin C ditemukan diberbagai jenis makanan seperti sayuran dan buah-buahan terutama buah segar [1].

Vitamin C merupakan vitamin yang tergolong larut dalam air. Vitamin C dapat berbentuk sebagai asam L-Askorbat yang mempunyai keaktifan sebagai vitamin C. Asam askorbat sangat mudah teroksidasi secara reversibel menjadi asam L-dehidroaskorbat. 
Asam L-dehidroaskorbat secara kimia sangat labil dan dapat mengalami perubahan lebih lanjut menjadi asam L-diketogulonat yang tidak memiliki keaktifan Vitamin C [2].

Sebagian besar masyarakat Indonesia sangat menggemari berbagai makanan pedas yang terbuat dari bumbu berbahan dasar cabai, akan tetapi banyak masyarakat yang tidak mengetahui manfaat cabai untuk kesehatan, salah satunya adalah cabai mempunyai kandungan vitamin $\mathrm{C}$ yang tinggi dan mempunyai manfaat yang besar untuk kesehatan. Karena sifat vitamin C yang mudah rusak karena oksidasi diperlukan penanganan pasca panen cabai, biasanya masyarakat kurang memperhatikan penyimpanan yang baik dari cabai tersebut. Kerusakan dapat terjadi karena pengemasan yang kurang baik. Untuk mencegah kerusakan pada cabai, diperlukan pengemasan dan temperatur suhu yang relatif rendah.

Di Indonesia jenis cabai yang paling banyak di konsumsi adalah cabai rawit dan cabai merah. Adapun penelitian yang telah dilakukan untuk perbandingan kadar vitamin $\mathrm{C}$ pada cabai rawit dan cabai merah didapatkan hasil sebagai berikut, kadar vitamin $C$ pada cabai rawit sebesar $70 \mathrm{mg} / 100 \mathrm{~g}$ [3], sedangkan untuk kadar vitamin $\mathrm{C}$ pada cabai merah sebesar $150 \mathrm{mg} \mathrm{-} 200 \mathrm{mg} / 100 \mathrm{~g}$ [4].

Namun demikian, semakin lama cabai disimpan kadar vitamin $\mathrm{C}$ pada cabai akan berkurang karena cabai memiliki sifat mudah layu sehingga dalam penyimpanannya perlu penanganan khusus, yaitu biasanya di simpan dalam tempat tertutup, lemari pendingin yang suhunya rendah antara $3^{\circ}-8^{\circ} \mathrm{C}$ dan kelembabannya tinggi sekitar $90-95 \%$ agar tetap segar selama \pm 10 hari. Penyimpanan yang baik dapat memperpanjang umur dan kesegaran cabai. Cara yang biasa digunakan untuk menyimpan cabai yang ideal pada suhu $4^{\circ} \mathrm{C}[5]$.

Cara dan lama penyimpanan yang tepat perlu dilakukan untuk memperoleh mutu yang optimal. Karena berdasarkan teori yang ada semakin lama penyimpanan maka akan berpengaruh pada kandungan vitamin $C$ yang terdapat pada suatu bahan pangan baik sayursayuran maupun buah-buahan. Berhubung ada nilai lebih yang terdapat dalam cabai ditinjau dari gizi dan konsumsi masyarakat pada cabai, maka perlu dilakukan penelitian apakah ada pengaruh lama penyimpanan terhadap stabilitas vitamin C. Penelitian sebelumnya dari Refrensi [6], hasil penelitiannya adalah untuk kadar vitamin $C$ cabai rawit (Capsicum frutuscens $L$ ) segar adalah $82 \mathrm{mg} / 100 \mathrm{~g}$ dan kadar vitamin $\mathrm{C}$ pada cabai rawit yang disimpan (2, 4, 6 hari) masing masing adalah $69,1 \mathrm{mg} / 100 \mathrm{~g}, 54,06 / 100 \mathrm{~g}$, dan 38,2/100g. Sedangkan kadar vitamin C pada cabai merah besar (Capsicum annum $\mathrm{L}$ ) segar adalah 183,8 mg/100 g dan kadar vitamin C pada cabai merah besar yang disimpan adalah $173,9 \mathrm{mg} / 100 \mathrm{~g}, 157,6$ $\mathrm{mg} / 100 \mathrm{~g}, \quad 148,1 \mathrm{mg} / 100 \mathrm{~g}$. Berdasarkan penelitian yang telah dilakukan metode 
iodimetri memiliki beberapa kekurangan, karena pada pengerjaannya menggunakan mata sebagai alat visual yang menentukan titik akhir titrasi oleh karena itu apabila metode ini dilakukan oleh orang yang berbeda, maka hasil yang akan berbeda pula. Selain itu apabila dalam pengerjaan atau pembuatan reagen terdapat kesalahan, maka secara tidak langsung kadar yang diperolehpun tidak sesuai.

Salah satu analisis kuantitatif yang dapat digunakan untuk menetapkan kadar suatu bahan adalah spektrofotometri. Metode ini sangat cocok dipakai karena alat yang digunakan memiliki spesifikasi dengan membaca absorbansi dan panjang gelombang dari sumber yang dipancarkan. Spektrofotometri adalah suatu metode analisa yang didasarkan pada panjang gelombang spesifik dengan menggunakan monokromator prisma atau kisi fototube [7]. Kelebihan dari metode ini yaitu dapat menetapkan kuantitas zat yang sangat kecil artinya spektrofotometri memiliki ketelitian yang sangat tinggi sehingga sangat cocok untuk menentukan kadar suatu senyawa pada sampel yang akan diuji coba sehingga terjadinya kesalahan dapat di minimalisir. Penelitian kali ini juga bertujuan untuk mengetahui ada tidaknya pengaruh penyimpanan terhadap kadar vitamin $\mathrm{C}$ antara cabai rawit dan cabai merah besar yang masih segar dan yang disimpan di dalam lemari pendingin pada suhu $4^{\circ} \mathrm{C}$ menggunakan metode spektrofotometri.

\section{METODE PENELITIAN}

Penelitian ini merupakan penelitian eksperimental atau percobaan (experiment research) metode penelitian yg digunakan untuk mencari pengaruh treatment tertentu (perlakuan) dalam kondisi yg terkontrol (laboratorium). Dalam penelitian ini, vitamin C diukur dengan menggunakan spektrofotometri UV. Dimana vitamin $C$ dapat diukur dengan menggunakan panjang gelombang $265 \mathrm{~nm}$. Pengukuran kadar vitamin $C$ dilakukan pada hari pertama, kedua, keempat, dan keenam. Sampel yang digunakan pada penelitian ini adalah buah cabai rawit dan cabai merah. Konsentrasi

Teknik pengumpulan data dengan menghitung kadar vitamin $\mathrm{c}$ yang terdapat pada cabai rawit (Capscum frutuscens $L$ ) dan cabai merah besar (Capsicum annnum $L$ ) yang telah disimpan selama 2, 4 dan 6 hari menggunakan persamaan regresi linier dari kurva kalibrasi yang telah dibuat yaitu $Y=a x+$ b. Analisis data penelitian menggunakan "teknik analisis kuantitatif yang mengolah data bentuk angka" [8]. Data kuantitatif yang di peroleh dari pengukuran kadar Vitamin $\mathrm{C}$ dianalisis secara statistik menggunakan program komputer Stastistical Product and Service Solution (SPSS) dengan pendekatan uji nilai probabilitas $(\mathrm{P})$.

\section{HASIL DAN PEMBAHASAN}


Vitamin adalah zat-zat organik komplek yang diperlukan tubuh dalam jumlah sangat kecil dan pada umumnya tidak dibentuk oleh tubuh tetapi penting untuk melakukan fungsi metabolik. Karena vitamin adalah zat organik, maka vitamin dapat rusak karena penyimpanan dan pengolahan. Cabai dapat dicegah kerusakannya dengan pengemasan yang baik dengan temperatur suhu yang relatif rendah. Suhu rendah dapat menghambat berkembangnya mikrooganisme dan perubahan bahan kimia. Sesuai dengan teori yang ada bahwa seharusnya tidak terdapat perbedaan kadar vitamin C pada tiap kelompok. Hal ini dikarenakan pada suhu rendah dapat mengurangi kegiatan respirasi dan metabolisme yang terjadi pada jaringan cabai rawit. Asas dasar penyimpanan dingin adalah penghambatan respirasi oleh suhu tersebut [9]. Proses perombakan vitamin C merupakan serangkaian proses yang melibatkan suatu enzim askorbat oksidase yang bertanggung jawab terhadap perombakan senyawa asam askorbat menjadi asam dehidroaskorbat. Pada suhu dingin akan mempengaruhi laju reaksi dari enzim tersebut, karena pada dasarnya laju reaksi enzim akan lebih cepat ketika terjadi proses pemanasan.
Aktivitas enzim yang dihambat ini dapat mencegah proses oksidasi vitamin C. Sehingga penurunan kadar vitamin $C$ dapat dicegah.

Menurut referensi [10] penyimpanan pada suhu rendah dapat mengurangi kegiatan respirasi dan metabolisme, memperlambat proses penuaan, mencegah kehilangan air, dan mencegah kelayuan. Laju respirasi merupakan petunjuk yang baik untuk daya simpan buah dan sayuran sesudah dipanen. Intensitas respirasi dianggap sebagai ukuran laju jalannya metabolisme, dan oleh karena itu sering dianggap sebagai petunjuk mengenai potensi daya simpan buah dan sayuran.

Vitamin $\mathrm{C}$ yang diteliti pada penelitian kali ini berasal dari cabai rawit (Capsicum frutuscens L) dan cabai merah besar (Capsicum annum $\mathrm{L}$ ) yang segar dan disimpan di dalam lemari pendingin selama 2 hari, 4 hari dan 6 hari pada suhu $4^{\circ} \mathrm{C}$. Diharapkan dari adanya perlakuan penyimpanan ini dapat diketahui sejauh mana batas penyimpanan kadar vitamin C pada cabai rawit dan cabai merah besar. Suhu $4^{\circ} \mathrm{C}$ dipilih karena pada umumnya suhu tersebut merupakan suhu ideal untuk menjaga agar sayuran ataupun buah-buahan tetap terjaga kesegarannya.

Tabel 1 Perhitungan Kadar Vitamin C Cabai Rawit 


\begin{tabular}{|c|c|c|c|c|c|c|c|c|}
\hline $\begin{array}{l}\text { Hari } \\
\text { ke- }\end{array}$ & $\begin{array}{c}\text { Panjang } \\
\lambda\end{array}$ & $\mathrm{Fp}$ & w (g) & Abs & $\begin{array}{l}\text { Kadar } \\
\text { Vit C } \\
(\mathrm{mg} / \mathrm{L})\end{array}$ & $\begin{array}{c}\text { Kadar } \\
\text { Vit C } \\
(\mathrm{mg} / \mathrm{gr})\end{array}$ & $\begin{array}{c}\text { Standard } \\
\text { Deviasi }\end{array}$ & $\begin{array}{c}\text { Rata - } \\
\text { Rata } \\
(\mathrm{mg} / \mathrm{gr})\end{array}$ \\
\hline \multirow{4}{*}{0} & 265,6 & 2500 & 20,0055 & 0,599 & 0,71111 & 88,8645 & \multirow{3}{*}{ $\pm 1,39$} & \multirow{3}{*}{88,19} \\
\hline & 266,2 & 2500 & 20,0057 & 0,600 & 0,71313 & 89,1160 & & \\
\hline & 266,6 & 2500 & 20,0052 & 0,590 & 0,69293 & 86,5936 & & \\
\hline & 266,6 & 2500 & 20,0053 & 0,568 & 0,64848 & 81,0391 & \multirow{3}{*}{ $\pm 1,02$} & \multirow{3}{*}{82,04} \\
\hline \multirow[t]{2}{*}{2} & 266,4 & 2500 & 20,0057 & 0,570 & 0,65253 & 81,5424 & & \\
\hline & 266,8 & 2500 & 20,0054 & 0,578 & 0,66869 & 83,5633 & & \\
\hline \multirow{3}{*}{4} & 266,8 & 2500 & 20,0055 & 0,557 & 0,62626 & 78,2613 & \multirow{3}{*}{ $\pm 2,05$} & \multirow{3}{*}{78,42} \\
\hline & 266,6 & 2500 & 20,0054 & 0,562 & 0,63636 & 79,5240 & & \\
\hline & 266,6 & 2500 & 20,0056 & 0,554 & 0,62020 & 77,5036 & & \\
\hline \multirow{3}{*}{6} & 267,4 & 2500 & 20,0050 & 0,564 & 0,64040 & 80,0305 & \multirow{3}{*}{ $\pm 1,34$} & \multirow{3}{*}{78,17} \\
\hline & 267,2 & 2500 & 20,0057 & 0,558 & 0,62828 & 78,5130 & & \\
\hline & 267,4 & 2500 & 20,0056 & 0,548 & 0,60808 & 75,9888 & & \\
\hline
\end{tabular}

Keterangan : $\mathrm{fp}=$ Faktor pengenceran Abs = Absorbansi

$\mathrm{W}=$ Berat sampel Panjang $\lambda=$ Panjang gelombang

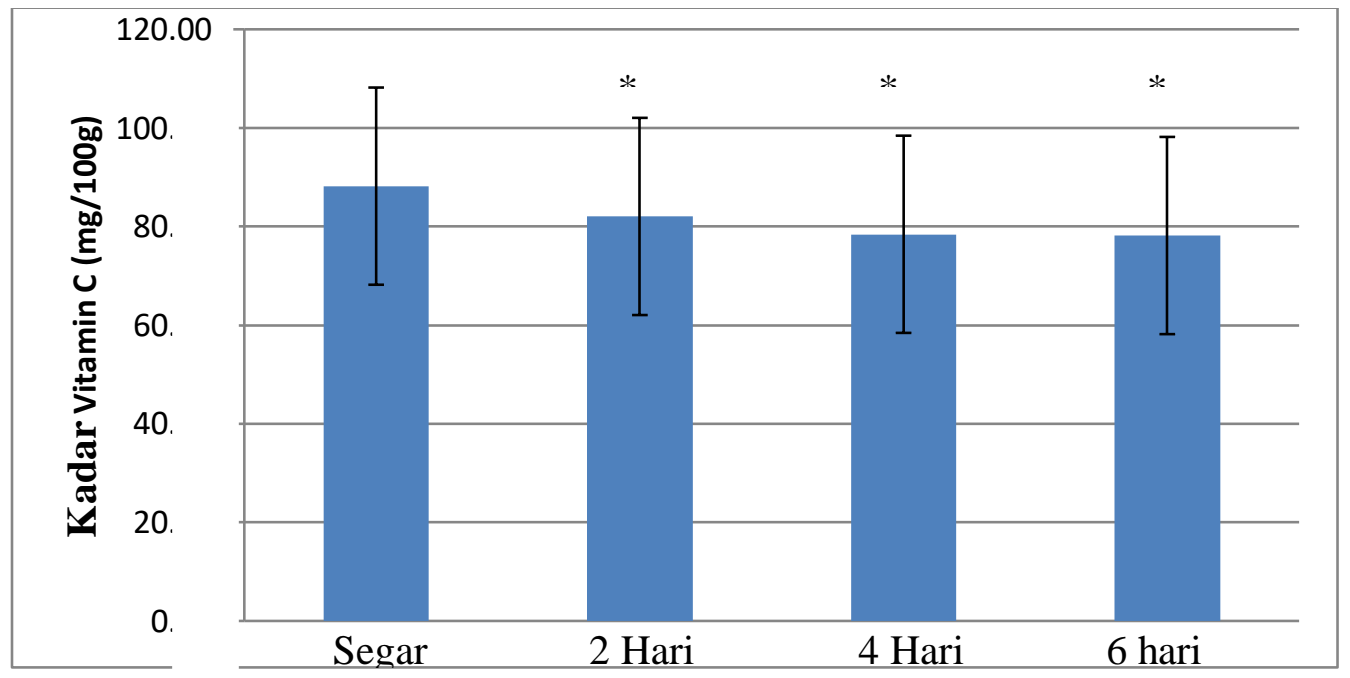

Gambar 1. Grafik standar deviasi dan kadar rata rata vitamin C cabai rawit Keterangan $=$ Hasil dinyatakan dalam rata-rata \pm standar deviasi $(n=3)$. Uji ANOVA dilanjutkan dengan hasil uji Post Hoc digunakan untuk evaluasi hasil sign. ${ }^{*} \mathrm{P}<0,05$ - berbeda bermakna dengan kelompok segar. 
Berdasarkan Tabel 1 dan Grafik 1 terlihat bahwa terdapat perbedaan bermakna antara semua kelompok penyimpanan dengan kelompok segar pada cabai rawit. Interpretasi ini didapat berdasarkan uji statistik ANOVA. Berdasarkan hasil penelitian kadar vitamin C pada cabai rawit didapatkan bahwa penyimpanan 2 hari, 4 hari dan 6 hari mempengaruhi kadar vitamin $\mathrm{C}$ yang ada pada cabai rawit segar. Hal ini dapat dilihat pada Tabel 1 dan Gambar 1 yang menunjukkan bahwa terdapat perbedaan bermakna antara cabai rawit pada kelompok penyimpanan 2 hari, 4 hari dan 6 hari dibandingkan dengan cabai rawit pada kelompok segar. Kemudian dilakukan uji statistik meliputi uji distribusi normal dan uji varians yang dilakukan terhadap kelompok cabai rawit. Dari hasil uji statistik menyatakan bahwa data terdistribusi normal dan homogen sehingga dapat dilakukan uji ANOVA, yang hasilnya menyatakan terdapat satu kelompok yang berbeda dari empat kelompok uji. Kemudian dari uji Post Hoc terlihat bahwa kelompok pada penyimpanan empat dan enam hari tidak berbeda bermakna. Namun berdasarkan uji statistik tersebut, kelompok penyimpanan selama 2 hari, 4 hari dan 6 hari memiliki kadar vitamin C yang berbeda bermakna dengan kadar vitamin C kelompok segar, sehingga dapat disimpulkan bahwa $\mathrm{H}_{0}$ ditolak, yang artinya kadar vitamin $\mathrm{C}$ pada cabai rawit tidak dapat terjaga kadarnya selama 2 hari, 4 hari dan 6 hari dalam lemari pendingin pada suhu $4^{\circ} \mathrm{C}$.

Penurunan dapat terjadi kemungkinan disebabkan karena tertundanya penguapan air yang menyebabkan struktur sel yang semula utuh menjadi layu. Dimana enzim askorbat oksidase tidak dibebaskan oleh sel sehingga tidak mampu mengoksidasi vitamin C lebih lanjut menjadi senyawa yang tidak mempunyai aktivitas vitamin C lagi. Tetapi apabila sel mengalami kelayuan enzim askorbat oksidase akan dibebaskan dengan cara kontak langsung dengan asam askorbat sehingga vitamin C mengalami kerusakan [11].

Pada penanganan pasca panen cabai, biasanya masyarakat kurang memperhatikan penyimpanan yang baik dari cabai tersebut. Kerusakan dapat terjadi karena pengemasan yang kurang baik. Menurut referensi [12], daun pisang biasanya digunakan sebagai pelindung produk pertanian karena dianggap dapat mencegah penguapan dari produk bahan pangan akibat pengaruh udara panas dari lingkungan luar.

Tabel 2. Standar Deviasi dan Kadar Rata-Rata Vitamin C Cabai Merah 
Analisís Pengaruh Penyimpanan Terhadap Kadar Vitamin C Pada Cabai Rawit (Capsícum Frutuscens $\mathcal{L}$ ) Dan Cabai Merah Besar (Capsícum Annum L) Dengan Metode Spektrofotometri

\begin{tabular}{ccccccccc}
\hline $\begin{array}{c}\text { Hari } \\
\text { ke- }\end{array}$ & Panjang $\lambda$ & Fp & W (g) & Abs & $\begin{array}{c}\text { Vit C } \\
(\mathrm{mg} / \mathrm{L})\end{array}$ & $\begin{array}{c}\text { Vit C } \\
(\mathrm{mg} / \mathrm{gr})\end{array}$ & $\begin{array}{c}\text { Standar } \\
\text { Deviasi }\end{array}$ & $\begin{array}{c}\text { Rata-rata } \\
(\mathrm{mg} / \mathrm{gr})\end{array}$ \\
\hline \multirow{2}{*}{0} & 265,2 & 2500 & 20,0055 & 0,568 & 0,6485 & 81,0383 & & \\
& 265,4 & 2500 & 20,0054 & 0,570 & 0,6525 & 81,5436 & $\pm 0,51$ & 8154,4052 \\
& 265,4 & 2500 & 20,0050 & 0,572 & 0,6566 & 82,0502 & & \\
\hline & 265,2 & 2500 & 20,0055 & 0,545 & 0,6020 & 75,2318 & & \\
& 265,2 & 2500 & 20,0056 & 0,538 & 0,5879 & 73,4643 & $\pm 0,89$ & 7439,0195 \\
& 265 & 2500 & 20,0055 & 0,542 & 0,5960 & 74,4745 & & \\
4 & 264,6 & 2500 & 20,0049 & 0,418 & 0,3455 & 43,1712 & & \\
& 262,4 & 2500 & 20,0050 & 0,412 & 0,3333 & 41,6563 & $\pm 0,77$ & 4249,7510 \\
& 263,2 & 2500 & 20,0055 & 0,416 & 0,3414 & 42,6650 & & \\
\hline \multirow{6}{*}{6} & 265,6 & 2500 & 20,0054 & 0,417 & 0,3434 & 42,9177 & & \\
& 265,4 & 2500 & 20,0053 & 0,417 & 0,3434 & 42,9179 & \pm 0.17 & 4283,3482 \\
& 265,4 & 2500 & 20,0056 & 0,416 & 0,3414 & 42,6648 & & \\
\hline
\end{tabular}

Keterangan $: \mathrm{fp}=$ Faktor pengenceran Abs = Absorbansi

$\mathrm{W}=$ Berat sampel Panjang $\lambda=$ Panjang gelombang

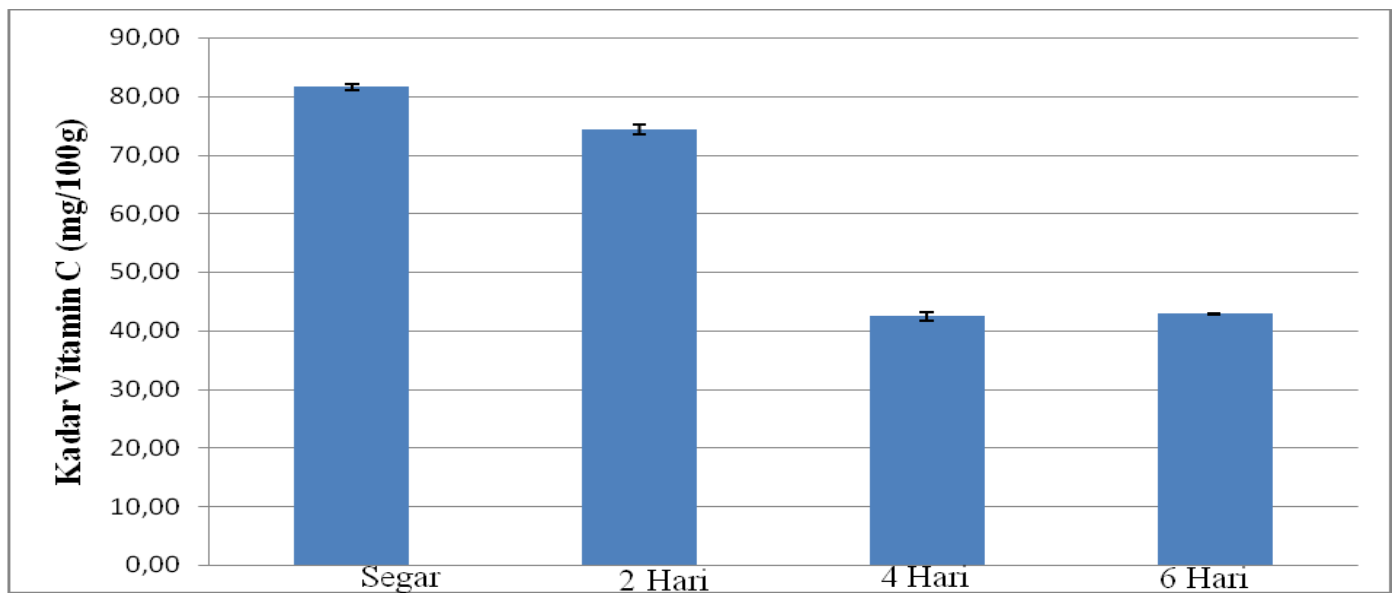

Gambar 2 Grafik standar deviasi dan kadar rata rata vitamin C

Keterangan $=$ Hasil dinyatakan dalam rata-rata \pm standar deviasi $(\mathrm{n}=3)$. Uji Kruskal Wallis dilanjutkan dengan hasil uji Man Whitney digunakan untuk evaluasi hasil sign. * $P<0,05$ - berbeda bermakna dengan kelompok segar 
Berdasarkan Tabel 2 dan Grafik 2 terlihat bahwa terdapat perbedaan bermakna antara semua kelompok cabai dengan kelompok segar. Hasil penelitian kadar vitamin C pada cabai merah besar didapatkan bahwa penyimpanan 2 hari, 4 hari dan 6 hari mempengaruhi kadar vitamin $\mathrm{C}$ yang ada pada cabai merah besar segar. Hal ini dapat dilihat pada Tabel 2 dan Gambar 2 yang menunjukkan bahwa terdapat perbedaan bermakna antara cabai rawit pada kelompok penyimpanan 2 hari, 4 hari dan 6 hari dibandingkan dengan cabai merah besar pada kelompok segar. Kemudian dilakukan uji statistik yang meliputi uji distribusi normal dan uji varians yang dilakukan terhadap kelompok cabai merah besar. Dari hasil uji statistik menyatakan bahwa data tidak terdistribusi normal, namun setelah dilakukan uji varians data dari kelompok uji homogen. Karena syarat untuk melakukan uji ANOVA tidak terpenuhi karena data tidak terdistribusi normal maka dilakukan uji alternatif lain yakin uji Kruskal Wallis. Berdasarkan uji statistik tersebut, kelompok penyimpanan selama 2 hari, 4 hari dan 6 hari memiliki kadar vitamin $\mathrm{C}$ yang berbeda bermakna dengan kadar vitamin C kelompok segar, sehingga dapat disimpulkan bahwa $\mathrm{H}_{0}$ ditolak yang artinya, kadar vitamin $\mathrm{C}$ pada cabai merah tidak dapat terjaga kadarnya selama 2 hari, 4 hari dan 6 hari penyimpanan di dalam lemari pendingin pada suhu $4^{\circ} \mathrm{C}$. Sama halnya dengan cabai rawit, yang menyatakan bahwa kelayuan berpengaruh dalam proses rusaknya vitamin C pada cabai merah besar yang terjadi karena adanya proses oksidasi sehingga menyebabkan kadar vitamin C pada cabai merah besar tidak terjaga selama penyimpanan.

Secara garis besar dari penelitian yang telah dilakukan, penelitian kali ini yakni "analisis pengaruh penyimpanan terhadap kadar vitamin C pada cabai rawit dan cabai merah dengan metode spektrofotometri" dapat dinyatakan bahwa penyimpanan selama 2 hari atau lebih tidak dapat menjaga kadar vitamin $C$ yang ada pada cabai rawit dan cabai merah besar. Oleh karena itu sebaiknya cabai rawit maupun cabai merah dapat langsung dikonsumsi atau paling tidak dikonsumsi dengan penyimpanan di dalam lemari pendingin selama tidak lebih dari 1 hari, karena setelah penyimpanan 2 hari atau lebih, vitamin $C$ mengalami penurunan yang disebabkan oleh kelayuan dan oksidasi, sehingga manfaat dari vitamin $\mathrm{C}$ sendiri tidak hilang.

Salah satu faktor penurunan kadar vitamin C pada cabai merah kemungkinan disebabkan karena adanya proses kelayuan. Kelayuan sendiri adalah suatu tahap normal yang selalu terjadi dalam siklus tanaman. Kelayuan merupakan hasil perubahanperubahan yang terjadi dalam sel, dinding menjadi lebih tipis, degradasi mitokondria, klorofil menghilang, kandungan protein menurun, kegiatan pernafasan dan fotosintesa 
Analisis Pengaruh Penyimpanan Terhadap Kadar Vitamin C Pada Cabai Rawit (Capsícum Frutuscens L) Dan Cabai Merah Besar (Capsícum Annum L) Dengan Metode Spektrofotometrí

menurun serta sifat permeabilitas membran sel juga berubah.

Selain itu penambahan bobot terjadi pada cabai merah besar yang disebabkan karena adanya perbedaan tekanan antara cabai merah dengan tempat penyimpanan. Semakin banyak uap air yang masuk ke cabai merah, maka bobot cabai merah semakin bertambah dan akan semakin peka terhadap kerusakan. Lapisan eksokarpium berupa jaringan epidermis yang tersusun rapat yang menyebabkan permeabilitasnya terhadap uap air. Permeabilitas terhadap uap air dan udara ini menyebabkan cabai rawit secara alami mampu berperan mengatur kelembapan dari ruang penyimpanan, sehingga kadar vitamin C yang ada pada cabai rawit lebih tahan walaupun selama penyimpanan 6 hari tetap mengalami penurunan, tetapi penurunan kadar vitamin $\mathrm{C}$ pada cabai rawit tidak seperti cabai merah besar.

\section{KESIMPULAN}

Kesimpulan dari penelitian ini adalah

1. Lama penyimpanan akan berpengaruh terhadap kadar vitamin $\mathrm{C}$ pada cabai rawit dan cabai merah besar

2. Penyimpanan selama 2 hari atau lebih tidak dapat menjaga kadar vitamin $\mathrm{C}$ yang ada pada cabai rawit dan cabai merah besar.

\section{DAFTAR PUSTAKA}

1. Winarno. 1991. Kimia Pangan dan Gizi. Jakarta : PT Gramedia Pustaka Utama

2. Hasan, 2013. Manfaat Cabai Rawit (Capsicum frutuscensL) dalam Pemenuhan Kebutuhan Tubuh. http://imbang.staff.umm.ac.id/files/2010/02 /Klasifikasi

dan Metabolisme vitamin imbang.pdf.

diakses 26 April 2015

3. Cahyono, 2003.Cabai Rawit Tekhnik Budidaya dan Analisis Usaha Tani. Kanisius. Yogyakarta. Di dalam "Rachmawati, 2009. Pengaruh Suhu dan Lama Penyimpanan Terhadap Kandungan Vitamin C, Pada Cabai Rawit Putih (Capsicum Frutecens). Bali : Jurnal Biologi XIII (2): 36-40 Universitas Udayana.

4. Johnson, 1998. Ascorbic acid. In: Handbook of vitamins (Edited by: Rucker RB, Sultie JW, McCornick, DB, Machlin LJ), Marcel Dekker Inc, New York p: 529585. Di dalam "Rachmawati, 2009. Pengaruh Suhu dan Lama Penyimpanan Terhadap Kandungan Vitamin C, Pada Cabai Rawit Putih (Capsicum Frutecens)“. Bali: Jurnal Biologi XIII (2): 36-40 Universitas Udayana.

5. Asgar, 2009. Penanganan Pascapanen Berapa Jenis Sayuran, Jurnal Holtikultura (7) 1:554-567. Makassar. Di dalam "Muh. Taufik, 2010. Analisis Pendapatan Usaha Tani Dan Penanganan Pascapanen Cabai Merah". Jurnal Litbang Pertanian 2011. 
6. Jahrani, M. 2014.Analisis Pengaruh Penyimpanan Terhadap Kadar Vitamin $C$ Pada Cabai Rawit (Capsicum frutuscens L) dan Cabai Merah (Capsicum annum L) dengan Metode lodimetri. Palangka Raya: Karya Tulis IImiah Program Sudi D - III Farmasi Universitas Muhammadiyah Palangkaraya.

7. Khopkar, S. M. 2002 "Konsep Dasar Kimia Analitik", Jakarta : Universitas Indonesia

8. Notoatmodjo, S. 2005. Metodologi Penelitian Kesehatan. Jakarta : Rineka Cipta

9. Pantastico, E. B 1997. Fisiologi Pasca Panen. UGM Press. Yogyakarta. Di dalam "Nurhayati Safaryani, 2007. Pengaruh Suhu dan Lama Penyimpanan terhadap Penurunan Kadar Vitamin C Brokoli (Brassica oleracea L)".
10. Wills, R.A.H., T.H Lee, D.Graham,W.B McGlasson, E.G. Hall.1981. Postharvest An Introduction to the Physiology and Handling of Fruit and Vegetables. New South Wales University Press. Sidney. Di dalam "Nurhayati Safaryani, 2007. Pengaruh Suhu dan Lama Penyimpanan terhadap Penurunan Kadar Vitamin C Brokoli (Brassica oleracea L).

11. Gaman, P.M. dan K.B Sherrington. 1992. IImu Pangan, Pengantar IImu Pangan, Nutrisi dan Mikrobiologi. Universitas Gajah Mada. Yogyakarta

12.

13. Sabana, S. 2000. Kemasan Sebelum Kertas dan Plastik. Jurnal Seri Rupa dan Design. Vol. 1. Bandung 